\title{
Imaging of psoriatic nail disease pre and post anti-TNF therapy shows persistent subclinical inflammation despite good clinical response
}

\author{
Zoe Ash", Richard Hodgson, Andrew Grainger, Sibel Z Aydin, Concepcion Castillo-Gallego, Ai Lyn Tan, \\ Helena Marzo-Ortega, Dennis McGonagle
}

From Northern and Yorkshire Deaneries Annual Rheumatology Conference

York, UK. 26 September 2012

\section{Background}

In psoriatic arthritis (PsA), nail disease is intimately linked to the presence of DIP joint enthesitis and arthritis. Nail disease has been shown in clinical trials to respond to treatment with TNF inhibitors. We used high resolution MRI to assess whether improvements in psoriasis-related nail disease correlated to improvements in associated DIP joint enthesitis, osteitis and synovitis during TNF inhibitor therapy.

\section{Methods}

Nine patients with psoriatic nail disease in addition to active skin or joint involvement were recruited prior to the commencement of TNF inhibitor therapy. All patients were TNF inhibitor naive at baseline. Assessments at baseline and six months included: clinical assessment, ultrasound of the nails and peripheral entheses and high resolution MRI scanning of one finger. Peripheral ultrasound enthesopathy was scored according to inflammatory and chronic findings, with the sonographer blinded to disease state. DIP joint MRI scans were scored by blinded paired analysis by two musculoskeletal radiologists.

\section{Results}

The mean patient age was 39, 2/9 patients were female. Seven patients had co-existent PsA, of whom all had DIP involvement. TNF prescription was made according to NICE guidelines. Five patients received etanercept and four adalimumab. One psoriasis patient was withdrawn at five months due to skin non-response. The results are presented here for the eight patients who completed the study.

Table 1

\begin{tabular}{|c|c|c|c|}
\hline & Baseline & Six $n$ & \\
\hline \multirow[t]{5}{*}{ Clinical assessment } & PASI & 5.25 & 0.76 \\
\hline & mNAPSI & 26 & 7 \\
\hline & Swollen joint count & 11 & 1 \\
\hline & Tender joint count & 11 & 1 \\
\hline & SPARCC enthesitis index & 3.1 & 0.4 \\
\hline \multirow[t]{3}{*}{ Peripheral entheseal ultrasound assessment } & Total peripheral enthesopathy ultrasound score & 27.8 & 21.6 \\
\hline & Inflammation score related to power Doppler changes & 1.0 & 0.1 \\
\hline & Chronic enthesopathy score & 11.8 & 9.9 \\
\hline
\end{tabular}

Clinical and ultrasound assessments, all reported as mean. Arthritis outcome measures reported for PsA patients only.

\footnotetext{
* Correspondence: Z.Ash@leeds.ac.uk

Section of Musculoskeletal Disease, Leeds Institute of Molecular Medicine,

University of Leeds and NIHR Leeds Musculoskeletal Biomedical Research Unit, Leeds Teaching Hospitals, Leeds, UK
}

(c) 2013 Ash et al; licensee BioMed Central Ltd. This is an Open Access article distributed under the terms of the Creative Commons B. Wed Central Attribution License (http://creativecommons.org/licenses/by/2.0), which permits unrestricted use, distribution, and reproduction in any medium, provided the original work is properly cited. 
Marked improvements were seen in clinical parameters (skin, joints and nails) as well as peripheral entheseal ultrasound assessments (Table 1). Baseline MRI scans showed DIP enthesitis, osteitis or synovitis in all PsA patients. Follow-up MRI scans showed persistent inflammatory changes in the DIP joint, distal phalanx and the soft tissues around the nail.

\section{Conclusions}

In keeping with RCT data, a good clinical response for arthritis, skin and nail disease was seen with anti-TNF therapy in patients with psoriatic nail disease. This exploratory imaging study however shows persistent ongoing subclinical inflammation (osteitis, synovitis and enthesopathy) at six months. This could relate to either a time lag in imaging improvement or the sensitivity of the imaging techniques used.

Published: 14 February 2013

doi:10.1186/1471-2474-14-S1-A7

Cite this article as: Ash et al:: Imaging of psoriatic nail disease pre and post anti-TNF therapy shows persistent subclinical inflammation despite good clinical response. BMC Musculoskeletal Disorders 2013 14(Suppl 1):A7.
Submit your next manuscript to BioMed Central and take full advantage of:

- Convenient online submission

- Thorough peer review

- No space constraints or color figure charges

- Immediate publication on acceptance

- Inclusion in PubMed, CAS, Scopus and Google Scholar

- Research which is freely available for redistribution

Submit your manuscript at www.biomedcentral.com/submit
C Biomed Central 